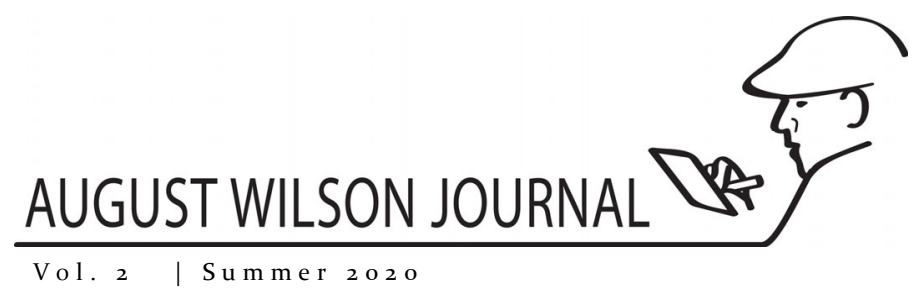

\title{
Reframing the Blues as a Performance Strategy in after august
}

\author{
By Omiyẹmi Artisia Green \\ Associate Professor of Theatre and Africana Studies, William \& Mary
}

While affirming the existence of protest expression within the blues, Maley makes a well-appreciated point that such retorts are generally more covert and coded with allusions, innuendo, and misdirection that are only accessible to the initiated.

- Omiyẹmi Artisia Green

\begin{abstract}
An analysis and review of Patrick Maley's after august regarding the topic of blues and how the subject is used in a variety of methods associated with August Wilson's American Century Cycle and other related works.

Keywords

August Wilson, American Century Cycle, after august, Blues, Identity Crafting, Patrick Maley
\end{abstract}

after august is structured in two parts: 1) Blues Dramaturgy and 2) Performance, Identity, and Reimagining American Drama with an equal number of chapters in each half. In the first chapter, "Blues and the Social Human" Maley clarifies the philosophical system at work in the blues of which Wilson so often spoke of in relation to the American Century Cycle. Taking up the task of peeling back the aesthetic layers of early blues formations, Maley defines the tradition as a performance strategy for selfdefinition, carefully dismantling misperceptions that the formation, which developed in the tensions of the post-Reconstruction South, is merely a response to Jim Crow oppression. Drawing on a robust interdisciplinary archive of blues, literary and performance scholars, as well as activists, he theorizes rather that the blues is an ethos of Black selfhood, a mindset, and attitude, cultivated into an aesthetic and purposed to develop "personal [and] communal identity" (19). Like

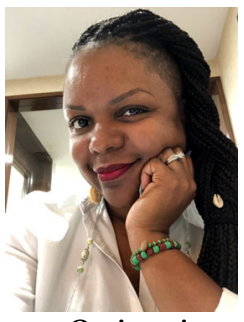

Omiyẹmi Artisia Green Wilson's attention on the complexities of those impacted by history rather than history itself and his social project in developing the identity and spiritual disposition of Black Americans, the blues is an ontology and a manner of locating and expressing a complex humanity rather than a documentation of responses to dehumanization. While affirming the existence of protest expression within the blues, Maley makes a wellappreciated point that such retorts are generally more covert and coded with allusions, innuendo, and misdirection that are only accessible to the initiated.

In "I Am the Blues": August Wilson as Bluesman," Maley contends that Wilson is not just a playwright whose dramaturgy was birthed from a matrifocal blues womb, his own mother, and his blood's memory, but that he is in fact a bluesman who performed a blues expression-theater-in his identity crafting. That is, in contemplation of $20^{\text {th }}$ century 
forms of oppression and injustice against himself, his mother, and the dehumanization of Black Americans more broadly, Wilson's impulse was to make a "blues art" that would serve to (re)construct Black American identities and notions of community in order to facilitate self-actualization. Moving beyond usual discussions of influence, themes, and blues music within the Cycle, Maley gives necessary critical treatment to Wilson's untheorized solo performance, How I Learned What I Learned and demonstrates how Wilson performs, through that work, "a blues sensibility" that is representative of his dramaturgy in the American Century Cycle. His estimation is that through writing and performing How I Learned, Wilson 1) demonstrates how similar he is to the characters of the Cycle-men and women of dignity and purpose-whose "becoming relies on an antiphonal relationship with others in the community" (57), and 2) embodies a core principle of the blues aesthetic as characterized by Kalamu ya Salaam ${ }^{1}$. Thus, a blues persons' social becoming is in part, due to the performance of their challenges and demonstration of their values, and the resultant community sanctioning of their humanity (43).

In the third chapter, "August Wilson's Blues," Maley departs from existing scholarship which largely considers blues as music applied in specific plays or as a revisionist lens through which to rewrite or reinvestigate history more broadly and continues to opine that the blues is an organizing metaphysical ethos that transcends music. Moving from Wilson's embodiment of a blues sensibility in the previous chapter, here Maley first proposes that the pre-Cycle plays (Jitney, Ma Rainey, and Fences) allowed Wilson to develop his blues sensibilities, a dramaturgy which crystalizes in his signature play, Joe Turner's Come and Gone. Maley uses this text as a zenith by which to measure blues elements in other areas of the Cycle. He introduces a new frame, the community ratified blues griot, to other distinctive elements of a Wilsonian play-the composition of the ensemble, its character driven plot, elements of spiritual realism, musicality, and the individualistic and misguided warrior. The latter, Maley argues, is the antithesis of the blues griot, whose understanding of self is in relationship to others in their community. While it is widely known that Wilson respected the warrior spirit, Maley suggests that this character disposition challenges the blues community Wilson crafts through his blues dramaturgy. What is true in this perspective (and no doubt Wilson was aware of this as well) is that it is the deep sense of individuality that becomes problematic for the warrior, not their willingness to fight or their profound sense of dignity and nobility. Maley concludes this chapter arguing for the antiphonal and double-voiced nature within the dialogue of any Wilsonian play. Thus, while signifying on the Western dramatic form and performing Black humanity, Maley suggests that Wilson simultaneously traverses the veil of the stage, levying indictments and explicit social critique against white audiences.

In the book's second half, Maley moves back and forth in time placing Wilson in conversation with predecessors and descendants of American drama such as Eugene O'Neill, Tennessee Williams, Katori Hall, Tarell Alvin McCraney, as well as Suzan-Lori Parks and Dominique Morisseau. In “God A'mighty, I Be Lonesomer'n Ever!” Maley reiterates a key feature of Black Theater and Wilson's blues dramaturgy-that community is essential to one's selfhood. In critiquing O'Neill and his oeuvre, Maley illuminates an often overlooked aspect of O'Neill's dramaturgy - whiteness as a "self-sustaining individualism" and a paradigm under which those seeking to become, look inward rather than towards the community in order to self-actualize (113). While concurrently casting a shadow on those within Wilson's Cycle who suffered from an "ethos of whiteness" (114), Maley calls attention to the same character flaw which led to the downfall of O'Neill's protagonists, often either clueless to this dimension of their character or unwilling to acknowledge the need for others in any project of identity crafting. A refreshing point in this chapter is Maley's decentering of

\footnotetext{
${ }^{1}$ American poet, author, filmmaker, and teacher from the 9th Ward of New Orleans.
} 
the tendency, particularly in theatre to view whiteness as some universal amoeba or neutralized middle ground, instead of the racial category that it is.

Still looking in the rear view mirror, Maley moves further into the $20^{\text {th }}$ Century for a comparative analysis between Wilson and Tennessee Williams in "Laws of Silence Don't Work." In this chapter, Maley advances earlier arguments of the similarity between the two writers and the need to further juxtapose them as opposed to limiting comparisons of Wilson's oeuvre to other Black writers such as Amiri Baraka, from whom Wilson was, agreeably, different. Maley argues that a dominant theme for both playwrights is the tension between their character's self-assessment and the social spheres in which they operate. Yet, in Maley's estimation there is a "radical lack of community" in Williams' work (144). Where Williams' men are always running to the metaphorical closet for safety (rarely private or a refuge), Maley asserts that Wilson's men, even the "culturally fragmented," always have a community willing to help them through their identity crafting.

The book concludes with "August Wilson's Legacy and Its Limits," which is in my assessment, a much more productive exploration than the two preceding chapters. Looking primarily at two contemporary dramatists-Katori Hall and Tarell Alvin McCraney, Maley argues that both carry on Wilson's legacy through their social identity crafting and dramatic contributions, providing a more comprehensive portrait of Black America. They pick up the Wilsonian ball in their blues dramaturgy (hometown focus, use of large ensembles, reliance on a communal ideology etc.), but carry it further down the field in their extensive treatment of women and/or queer Black men, notable absent explorations in the Cycle. Maley argues that for Hall's blues women, failure is a site of possibility and redirection, but it is a formidable project of self-crafting because Hall's women face defeats of extremely tall orders-murder, rape, HIV, and drug addiction among them. Yes, as he notes, in some regards the losses of Hall's women are similar to those of Wilson's and in others, more radical. However, Maley seems to imply that the opportunities for female self-crafting in the American Century Cycle (in the face of conventionality, rampant individualism, and "cultural fragmentation") is less difficult because they "are immersed in their social performances" with resolution despite lack of recognition of their humanity (186). I am hesitant to agree that self-crafting for Wilson's women is less difficult than it is for Hall's (and we must be careful here as we are comparing a multiplicity of identities among the women of these two writers). I think we often miss and/or misread some of the identity crafting practices within the social performances Wilson's women play.

Similar to Tennessee Williams, McCraney dramatizes explorations of unratified queerness, an aspect cursorily suggested in Ma Rainey's Black Bottom, but is generally speaking, conspicuously absent in the Cycle. Noting the similarity between their plays in "construction, habits, prejudices [and...] language" (188), Maley contends that McCraney carves out a new terrain in the legacy of Wilson's blues dramaturgy with his focus on Black queer identities (and I would add, through his use of an explicit Africanist dramaturgy, a feature that was much more latent and creolized through blues aesthetics and Western dramatic elements in Wilson's work).

Maley is to be commended. after august does what Wilson certainly was not obligated to do nor perhaps could articulate any further than he often did in interviews, given his limitations. The text-particularly its first half-expands our understanding of the blues as philosophical system and a performance strategy through which to craft identity and find freedom. For me, the least engaging aspect of the work was Maley's comparative treatment of O'Neill and Williams via a Wilsonian lens as I was unconvinced, particularly in the chapter on Williams that such an investigation was truly of consequence-in this particular book-especially given that neither O'Neill nor Williams bore any influence on Wilson and vice versa. Yet, undoubtedly critics, scholars, and audiences will find these two chapters useful. Maley's theorization of their work and partially their lived experience, through Wilson's blues sensibilities, highlights the dramatic limitations of both playwrights. 
\begin{tabular}{l|l|l} 
Vol. 2 Summer 2020 &
\end{tabular}

But perhaps of more magnitude is the credence such theorization gives to aesthetic methodologies of Black Theater, namely the importance and function of community. Notwithstanding, after august makes an important contribution to Wilson studies. It is a rigorously researched, well-written, and deft interdisciplinary investigation of one of America's most important Black dramatists and his legacy.

\section{Works Cited}

Maley, Patrick. after august: Blues, August Wilson and American Drama. Charlottesville: University of Virginia Press, 2019. 202 pp.

\section{Author Bio}

Omiyemi Artisia Green is Associate Professor of Theatre and Africana Studies, a W. Taylor Reveley, III Interdisciplinary Faculty Fellow, and Director of the Program in Africana Studies at William \& Mary. She is a director, dramaturg, and interdisciplinary scholar. 